\title{
STRATEGI KOMUNIKASI PEMASARAN WISATA BARU SETIGI DI GRESIK JAWA TIMUR
}

\author{
Uzlifatul Jannah $^{1}$, Agoes Moh. Moefad ${ }^{2}$ \\ ${ }^{1,2}$ Universitas Islam Negeri Sunan Ampel Surabaya \\ ${ }^{1}$ uzlifatul@gmail.com, ${ }^{2}$ agoes@gmail.com
}

Article Info

Received 2 Agustus 2019

Accepted 5 September 2019

Published 5 Oktober 2019

\section{Keyword:}

Strategi, Komunikasi

Pemasaran, Wisata

"Setigi"

\section{Abstract}

This article discusses how the tourism marketing communication strategy "Setigi" in Sekapuk Village, Ujungpangkah District, Gresik Regency. The purpose of this study was to determine the marketing communication strategy of Village-Owned Enterprises (Bumdes) and tourism awareness groups (Pokdarwis) "Pelangi" in tourism marketing. limestone hill "Setigi" to attract visitors. This study uses a qualitative-descriptive approach based on integrated marketing communication theory. The result of this research is the implementation of a marketing communication strategy carried out by Bumdes and Pokdarwis "Pelangi" in Sekapuk Village, Ujungpangkah District, Gresik Regency utilizing social media and collaborating with the youth community in the Gresik area, as well as collaborating with the Gresik Regency Tourism Office

Artikel ini membahas tentang bagaimana strategi komunikasi pemasaran wisata "Setigi" di Desa Sekapuk, Kecamatan Ujungpangkah, Kabupaten Gresik.Tujuan penelitian ini adalah mengetahui strategi komunikasi pemasaran Badan Usaha Milik Desa (Bumdes) dan kelompok sadar wisata (Pokdarwis) "Pelangi" dalam pemasaran wisata bukit kapur "Setigi" untuk menarik pengunjung. Penelitian ini menggunakan pendekatan kualitatif-deskriptif berdasarkan teori komunikasi pemasaran terpadu. Hasil penelitian ini adalah pelaksanaan strategi komunikasi pemasaran yang dilakukan oleh Bumdes dan Pokdarwis "Pelangi" di Desa Sekapuk, Kecamatan Ujungpangkah, Kabupaten Gresik memanfaatkan media sosial dan bekerjasama dengan komunitas anak muda di daerah Gresik, serta bekerjasama dengan Dinas Pariwisata Kabupaten Gresik. 


\section{Pendahuluan}

Indonesia di anugerahi berupa kekayan alam dan ragam budaya yang begitu indah. Sudah sepatutnya kita sebagai manusia memelihara alam kita sebaik mungkin. Dengan adanya potensi alam yang dimiliki, tentu saja mendorong adanya sebuah kegiatan pariwisata. Indonesia memiliki potensi yang kompetitif dibandingkan dengan negara lain dalam bidang industri pariwisata. Banyak keunikan dan keanekaragaman budaya dan wisata yang dimiiki Indonesia. Hal ini membuat pariwisata di Indonesia mengalami peningkatan jumlah kunjungan wisatawan baik domestik maupun mancanegara yang signifikan pada setiap tahunnya. Hal ini ditunjukan dalam Laporan Bulanan Data Sosial Ekonomi Juli 2018 (Publikasi BPS), dimana, jumlah kunjungan wisatawan mancanegara (wisman) selama Semester I (Januari-Mei) 2018 mencapai 6,17 juta kunjungan atau naik 11,89 persen dibandingkan dengan jumlah kunjungan wisman pada periode yang sama tahun 2017. Berdasarkan data dari Badan Pusat Statistik, sebelas provinsi yang paling sering dikunjungi oleh para turis adalah Bali sekitar lebih dari 3,7 juta disusul, DKI Jakarta, Daerah Istimewa Yogyakarta, Jawa Timur, Jawa Barat, Sumatera Utara, Lampung, Sulawesi Selatan, Sumatera Selatan, Banten dan Sumatera Barat. ${ }^{1}$

Pariwisata adalah kegiatan dinamis yang melibatkan banyak manusia serta menghidupkan berbagai bidang usaha. Di

${ }^{1}$ Badan Pusat Statistik, "Laporan Bulanan Data Sosial Ekonomi Juli 2018 (Publikasi BPS)", diakses, 28 Juli 2018. www.bps.go.id era globalisasi saat ini, sektor pariwisata akan menjadi pendorong utama perekonomian dunia dan menjadi industri yang mengglobal. Pariwisata akan memberikan banyak pemasukan bagi daerah yang sadar akan potensinya terhadap sektor pariwisata. ${ }^{2}$

Pariwisata ini merupakan suatu kebutuhan sekunder yang akan dipenuhi oleh manusia ketika kebutuhan primer telah tercapai. Pariwisata sendiri pada dasarnya adalah bagian yang tidak dapat dipisahkan dari kehidupan manusia terutama menyangkut kegiatan sosial dan juga ekonomi. Perkembangan pariwisata ini dilihat sebagai suatu cara yang tepat dan efisien dalam penggerak ekonomi rakyat karena sektor ini dianggap paling siap dari segi fasilitas, sarana prasarana dibandingkan sektor lainnya. Dengan harapan pariwisata ini dapat dikembangkan dalam suatu strategi pemberdayaan masyarakat melalui pengembangan pariwisata berbasis kerakyatan atau community-based tourism development. ${ }^{3}$

Sektor pariwisata merupakan kegiatan yang tak pernah mati dan menjadi hal yang sangat penting bagi suatu negara. Dengan adanya pariwisata, lebih dikhususkan untuk pemerintah daerah, objek wisata akan menjadi pemasukan bagi daerah itu sendiri. Dengan berkembanganya pariwisata, akan mendongkrak sektor yang lain, seperti: kunjungan wisatawan, ekonomi kreatif, membuka kesempatan kerja, mengurangi pengangguran. Sektor

\footnotetext{
${ }^{2}$ Ismayanti, Pengantar Pariwisata, (Jakarta: Grasindo, 2010 ), 1.

${ }^{3}$ Ismayanti, Pengantar, 3.
} 
pariwisata tidak bisa berdiri sendiri, dan harus didukung oleh kegiatan-kegiatan penunjang lainnya, yaitu: promosi wisata, fasilitas yang ditawarkan, akses transportasi dan tempat penginapan.

Pariwisata perlu ditingkatkan dan diperluas untuk meningkatkan penerimaan devisa, memperluas lapangan pekerjaan dan memperkenalkan kebudayaan. Pembinaan serta pengembangan pariwisata dilakukan dengan tetap memperhatikan terpeliharanya kebudayaan dan kepribadian lokal. Untuk itu perlu diambil langkah-langkah dan pengaturanpengaturan yang lebih terarah berdasarkan kebijaksanaan yang terpadu, antara lain bidang promosi, penyediaan fasilitas serta mutu dan kelancaran pelayanan.

Di dalam Strategi pemasaran yang dilakukan Obyek Wisala Alam di Indonesia menggabungkan History dan modernisasi menjadikan Wisata Alam sebagai tujuan utama wisata di Kota tersebut. Pemasaran pariwisata sangat kompleks sifatnya, dibandingkan dengan pemasaran barang-barang yang dihasilkan perusahaan manufaktur yang biasa kita kenal. Produk yang ingin dipasarkan sangat terikat dengan suplier yang menghasilkannya, instansi, organisasi atau lembaga pariwisata yang mengelolanya. Sedangkan Untuk memasarkan produk industri pariwisata bukan saja diperlukan koordinasi dan komunikasi di pemasaran saja namun juga branding dan diperlukan kerjasama yang baik antara organisasi yang bertanggung jawab dalam pengembangan pariwisata dengan semua pihak yang terlibat dan berkaitan dengan kegiatan pariwisata. Pada umumnya sebuah destinasi wisata itu di pengaruhi oleh Leisure Studies yaitu pemikiran bahwa pariwisata dengan semua aktivitas yang terkait didalamnya bukan merupakan fenomena yang dapat berdiri sendiri. Pariwisata merupakan bagian dari suatu sektor yang lebih luas, yaitu Leisure Industry. didalam Leisure Industry, kita mengenal empat komponen pembentuknya, yaitu sport, media communication, cultural dan tourism industry. ${ }^{4}$ Dimana dari empat komponen itu yang membranding tempat wisata menjadi lebih baik.

Begitupun dengan strategi bauran komunikasi pemasaran wisata baru yang dilakukan oleh BUMDES dan Pokdarwis Pelangi sebgaia pengelolah di wisata Bukit Kapur (SETIGI) dalam menarik pengunjung dalam dan menyumbangkan setiap rupiahnya bagi devisa negara maupun kesehjateraan wisata itu sendiri. Dapat dikatakan, keberhasilan suatu program pemasaran dalam bidang kepariwisataan sangat ditentukan oleh faktor kesamaan padangan terhadap peranan pariwisata bagi pembangunan daerah, Keuntungan dan mewujutkan visi dan misi daerah tersebut, karena itu sebelum program pemasaran dilaksanakan harus ada komitmen dari semua unsur seperti dalam membranding tempat tersebut terkait, bahwa pariwisata merupakan sektor ekonomi yang bersifat

${ }^{4}$ Rio Budi Prasadja Tan, Dipl.Tour, Kunci Sukses Memasarkan Jasa Pariwisata, (Jakarta, Penerbit Erlangga, 2010), 3. 
quick yielding dan merupakan agen of development bagi daerah itu. Pada dasarnya marketing menurut Kotler yaitu Pada kenyataannya, marketing identik dengan kegiatan mencari, menarik, dan memelihara hubungan baik dengan konsumen. ${ }^{5}$

J. Krippendorf, dalam bukunya Marketing At Tourisme merumuskan pemasaran pariwisata yaitu Marketing atau Pemasaran pariwisata adalah suatu sistem dan koordinasi yang harus dilakuakan sebagai kebijaksanaan bagi perusahaanperusahaan kelompok industri pariwisata, baik milik swasta atau pemerintah, dalam ruang lingkup lokal, regional, nasional, dan internasional untuk mencapai kepuasan wisatawan dengan memperoleh keuntungan yang wajar.

Di Kabupaten Gresik lebih tepatnya di Desa Sekapuk mempunyai kekayaan alam yang patut dilestarikan dan saat ini sudah dijadikan sebagai obyek wisata baru yaitu bukit kapur (SETIGI) oleh pemerintah daerah tersebut. Karena lokasinya yang sangat strategis dan bernilai tinggi. Wisata Bukit Kapur (SETIGI) dibangun pemerintah Desa Sekapuk dalam upaya pelestarian lokasi bekas galihan tambang batu kapur tersebut. Jika tidak ada upaya pencegahan atau pelestarian seperti ini, maka Desa Sekapuk akan kehilangan kekayaan alam tersebut.

Wisata Bukit Kapur (SETIGI) mulai dikunjungi masyarakat sejak 2016. Kemudian Pemerintah Desa meresmikan danmelakukan grand opening pada wisata tersebut pada tanggal 11 Mei 2017 oleh
Kepala Desa Sekapuk. Wisata alam bukit kapur setigi ini terdiri dari hamparan bukit kapur yang membentuk tebing, goa, dan lorong-lorong yang menjadi daya Tarik wisatawan untuk melakukan spot foto baik dengan keluarga, teman, maupun seorang diri. Dikarenakan seringnya wisatawan yang berkunjung ke wisata bukit kapur setigi yang menjadikan wisata alam tersebut sebgaia Icon nya Desa Sekapuk.

Di Kabupaten Gresik sendiri merupakan wilayah yang terletak di bagian utara Pulau Jawa, dan cukup dekat dengan Kota Surabaya. Kabupaten Gresik berbatasan dengan Kabupaten Sidoarjo, Kabupaten Lamongan, Kabupaten Mojokerto, Kota Surabaya, serta Selat Madura. Sebagai kota satelit Surabaya, Gresik memegang peran penting sebagai penyuplai perekonomian dan kebutuhan pokok Surabaya. Selain fakta tersebut, ternyata Kabupaten Gresik juga menyimpan potensi alam yang sangat menawan, baik dataran tingginya maupun keindahan pantainya. Apa saja tempat wisata yang cukup terkenal di Gresik diantaranya ada : wisata religi sunan giri, wisata pantai delegan, wisata taman petik buah naga, wisata pulau bawean, wisata bukit kapur setigi.

Dari beberapa wisata yang cukup terkenal di gresik peneliti memutuskan untuk membuat penelitian tentang mendeskripikan strategi bauran pemasaran obyek wisata baru di wisata bukit kapur SETIGI, dikarenakan wisata ini masih dibilang baru namun sudah sangat popular sosial media. Memang di kota gresik bukir

${ }^{5}$ Rio Budi Prasadja Tan, Dipl.Tour, Kunci Sukses, 49. 
kapur ada juga dibeberapa wilayah gresik antar lain ada di desa Suci, di Desa Cangaan, di desa Sekapuk, di desa dukun. Perbukitan yang sangat exotis seperti di beradaban kuno, goa-goa yang sangat menjulang, dan perbukitan yang menawan menjadikan wisata SETIGI ini mempunyai keunikan dari yang lain. Disisi lain letaknya yang mudah dijangkau dan sangat strategis. Dengan beberapa alasan tesebut peneliti ingin mengetahui strategi komunikasi pemasaran apa saja yang dilakukan pihak pengelola dalam memasarkan wisata baru ini dan cukup populer di sosial media. Karena masih baru mangkanya belum ada penelitian dari manapun tentang strategi pemasaran wisata ini. Dengan alasan ini peneliti memberanikan diri untuk melakukan penelitian di wisata ini.

Dapat dikatakan, keberhasilan suatu program pemasaran dalam bidang kepariwisataan sangat ditentukan oleh faktor kesamaan pandangan terhadap peranan pariwisata bagi pembangunan daerah, Keuntungan dan mewujutkan visi dan misi kota tersebut, karena itu sebelum program,pemasaran dilaksanakan harus ada komitmen dari semua unsur seperti dalam membranding tempat tersebut terkait, bahwa pariwisata merupakan sektor ekonomi yang bersifat quick yielding dan merupakan agen of development bagi daerah itu. Pada dasarnya marketing menurut Kotle pada kenyataannya, marketing identik dengan kegiatan mencari, menarik, dan

${ }^{6}$ Rio Budi Prasadja Tan, Dipl.Tour, Kunci Sukses, 49. memelihara hubungan baik dengan konsumen. ${ }^{6}$

Peran pengelolah wisata dari sebuah organisasi pemerintahan maupun organisasi kelompok sebagai komunikator dalam memasarkan sebuah daerah sangat dibutuhkan oleh suatu daerah yang memiliki obyek wisata. Terjadinya komunikasi yang efektif jika komunikator memiliki ethos atau credibility (ahli dan dapat dipercaya), memiliki daya tarik (attractiveness) dan kekuasaan (power). ${ }^{7}$ Serta diharapkan mampu bekerjasama dengan pemerintah atau dinas terkait. Sehingga pesan yang disampaikan diharapkan dapat diterima baik oleh komunikan, menghasilkan feedback atau umpan balik, dan terjadinya efek persuasif.

Pengelolah wisata sebagai komunikator harus memiliki kemampuan tersebut. Selain itu, dibutuhkan juga suatu promosi yang efektif karena meningkatkan penjualan. Dengan kata lain meningkatkan kunjungan wisatawan, sehingga hal ini dapat menarik minat para wisatawan untuk memilih Kabupaten Gresik sebagai tempat untuk berkreasi. Dari penjelasan diatas dapat ditarik kesimpulan bahwa ketertarikan seseorang akan sesuatu itu dipengaruhi oleh komunikator dan strategi komunikasi yang efektif. Meninjau kembali apa yang telah dijelaskan diatas mengenai tujuan pemasaran, kurangnya strategi pemasaran suatu daerah dikhawatirkan akan menyebabkan berkurangnya jumlah kunjungan wisatawan di Kabupaten Gresik yang

${ }^{7}$ Onong Uchjana Effendy, Ilmu Komunikasi (Teori dan Praktek), (Bandung: PT Remaja Rosdakarya, 2007), 24. 
nantinya juga akan berdampak buruk baik bagi pembangunan bahkan perekonomian daerah. Akan dirasa memprihatinkan jika ada suatu potensi wisata yang mampu menjadi maju dan berkembang malah kurang mendapatkan perhatian dari publik maupun dari dinas terkait. Dengan adanya pembentukan organisasi pengelolah wisata nantinya diharapkan ada sosok yang mampu menjadi seorang promotor untuk mempromosikan potensi wisata yang ada di daerah tersebut.

Pemilihan strategi merupakan langkah krusial yang memerlukan penanganan secara hati-hati dalam perencanaan komunikasi, sebab jika pemilihan strategi salah maka hasil yg diperoleh bisa fatal, terutama kerugian dari segi waktu, materi, dan tenaga. Konsep strategi komunikasi disini diletakkan sebagai bagian dari perencanaan komunikasi dalam mencapai tujuan yang ingin dicapai, sedangkan perencanaan strategi tidak lain adalah kebijaksanaan komunikasi dalam tataran makro untuk program jangka panjang. ${ }^{8}$

Menurut Thamrin Abdullah dan Francis Tantri, pemasaran adalah suatu sistem total dari kegiatan bisnis yang dirancang untuk merencanakan, menentukan harga, mempromosikan, mendistribusikan barang-barang dan jasa yang dapat memuaskan keinginan konsumen saat ini maupun konsumen potensial. $^{9}$

Menurut Dibb, Simin, Pride \& Ferrel, pemasaran didefinisikan sebagai aktivitas

${ }^{8}$ Hafied Cangara, Perencanaan Dan Strategi Komunikasi, (Jakarta: Raja Grafindo Persada, 2013), 44. individual dan organisasional yang memfasilitasi dan memperlancar hubungan pertukaran yang saling memuaskan dalam lingkungan yang dinamis melalui pengembangan, distribusi, promosi, dan penetapan harga barang, jasa dan gagasan. ${ }^{10}$

Jadi dari beberapa pengertian yang dikemukakan oleh beberapa ahli tersebut, maka dapat ditarik kesimpulan bahwa pemasaran merupakan kegiatan manusia baik itu individu maupun organisasi yang dirancang secara sistematis dan managerial yang diarahkan untuk memuaskan kebutuhan dan keinginan pelanggan serta tujuan perusahaan.

Jadi, istilah pemasaran jasa dalam dunia pariwisata itu sendiri merupakan sebuah tindakan atau cara yang diambil oleh pihak pengelolah yang dirancang untuk melayani dan memuaskan kepentingan konsumen atau pelanggan. Aktivitas dalam pemasaran pariwisata itu sendiri meliputi aktivitas dan alat untuk mempromosikan wisata secara konsisten dan efektif sebagai pilihan pariwisata bagi masyarakat. Dalam memasarkan sebuah produk ataupun jasa terdapat beberapa perangkat-perangkat pemasaran yang dapat dijadikan sebagai alat untuk menciptakan strategi pasar dalam mempertahankan keunggulan kompetitif dari para pesaing pasar. Perangkatperangkat tersebut dinamakan dengan istilah bauran pemasaran.

9 Thamrin Abdullah, dkk. Manaajemen Pemasaran, (Jakarta: PT. Raja Grafindo Persada, 2013), 2.

${ }^{10}$ Samsul Anam, dkk. Manajemen pemasaran, (Surabaya: IAIN Sunan Ampel Pers, 2013), 7. 
Pengertian bauran pemasaran itu sendiri menurut Buchari Alma adalah strategi mencampur kegiatan-kegiatan marketing, agar dicari kombinasi yang maksimal sehingga mendatangkan hasil yang memuaskan. Zeithaml dan Bitner juga menjelaskan bauran pemasaran adalah elemen-elemen organisasi perusahaan yang dapat dikontrol oleh perusahaan dalam melakukan komunikasi dengan tamu dan untuk memuaskan tamu. Kootler dan Amstrong mendefinisikan bauran pemasaran adalah perangkat pemasaran yang baik yang meliputi produk, penentuan harga, promosi, distribusi, digabungkan untuk menghasilkan respon yang diingikan pasar sasaran. ${ }^{11}$

Dari ketiga pendapat para ahli diatas dapat ditarik kesimpulan bahwasanya bauran pemasaran merupakan pencampuran atau penggabungan unsurunsur pemasaran dari suatu organisasi agar tercipta strategi yang tepat untuk mengimplementasikan strategi pemasaran.

Bauran pemasaran merupakan alat bagi pemasar yang terdiri dari berbagai unsur suatu program pemasaran yang perlu untuk dipertimbangkan agar implementasi strategi pemasaran dan positioning yang ditetapkan dapat berjalan dengan sukses. ${ }^{12}$

Bauran pemasaran pada umumnya memiliki empat unsur pemasaran yang biasa dikenal dengan 4P: product, price, place, dan promotion. Akan tetapi jika terdapat perbedaan antara pemasaran produk atau barang dengan pemasaran jasa

11 TipSerbaSerbi, "Pengertian Marketing Mix", diakses pada 22 Oktober 2018, http://tipsserbaserbi.blogspot.co.id/2016/02/penger tian-marketting-mix-4p-dan-7p.html?m=1 itu sendiri. Dalam pemasaran jasa, terdapat 3 unsur yang ditambahkan, yaitu people, process, dan customer services. ${ }^{13}$

Karakteristik atau sifat jasa berpengaruh pada proses pemberian jasa itu sendiri, dimana tahapan operasi hingga konsumsi merupakan suatu rangkaian yang tidak dapat dipisahkan serta mengikutsertakan baik konsumen dan pemberi jasa secara langsung, dengan kata lain terjadi interaksi secara langsung antara keduanya. Sebagai suatu bauran, unsurunsur tersebut saling mempengaruhi satu sama lain sehingga apabila salah satu tidak tepat pengorganisasiannya maka akan mempengaruhi strategi pemasaran secara keseluruhan.

Begitupun dengan strategi bauran pemasaran pariwisata yang dilakukan oleh pengelolah Wisata Bukit Kapur "SETIGI" di Gresik dalam menarik pengunjung ataupun para wisatawan agar mengunjungi dan menyumbangkan setiap rupiahnya bagi devisa negara maupun kesehjateraan Masyarakat setempat. Melihat begitu unik lokasinya dengan pemandangan yang indah di lokasi Wisata Bukit Kapur "SETIGI", serta melihat banyaknya pengunjng disetiap minggunya mengalami peningkatan, menggambarkan bahwa wisata bukit kapur "SETIGI" sangat diminati oleh wisatawan nasional maupun internasional.

12 M. Manullang, Esterlina Hutabarat, Manajemen Pemasaran Jasa, (Yogyakarta: Indomedia Pustaka, 2016), 26

${ }^{13}$ David Wijaya, "Pemasaran Jasa Pendidikan”, (Jakarta: Bumi Aksara, 2016), 68. 


\section{Kajian Pustaka}

\section{Makna Komunikasi Pemasaran}

Komunikasi pemasaran dapat dipahami dengan menguraikan dua unsur yang ada didalamnya yakni komunikasi dan pemasaran. Komunikasi adalah proses penyampaian sesuatu mengandung arti, lewat media maupun tidak yang berupa gagasan, ide, perasaan, pernyataan dan sebagainya dalam upaya mempengaruhi orang lain agar bertindak sesuai dengan apa yang dikehendaki. Dan juga diartikan Upaya yang sistematis untuk merumuskan secara tegar asas-asas penyampaian informasi serta pembentukan pendapat dan sikap. ${ }^{14}$ Sedangkan pengertian pemasaran adalah proses pemberian kepuasan kepada konsumen untuk mendapatkan laba atau strategi produk, promosi, dan penentuan harga yang bersifat unik serta dirancang untuk menghasilkan pertukaran yang saling menguntungkan dengan pasar yang dituju.

Dari kedua defenisi di atas, dapat disimpulkan bahwa pengertian komunikasi pemasaran adalah kegiatan komunikasi yang ditujukan untuk menyampaikan pesan kepada konsumen dan pelanggan dengan menggunakan sejumlah media dan berbagai saluran yang dapat dipergunakan dengan harapan terjadinya tiga tahap perubahan, yaitu: perubahan pengetahuan, perubahan sikap, dan perubahan tindakan yang dikehendaki. Hubungan antara pemasaran dengan komunikasi merupakan hubungan yang erat. Unsur komunikasi dan pemasaran tersebut dapat disusun menjadi sebuah model komunikasi untuk menjelaskan proses komunikasi pemasaran yang terjadi. Komunikasi dalam kegiatan pemasaran bersifat kompleks, artinya tidak sesederhana seperti ketika berbincangbincang dengan rekan sekantor, atau dengan keluarga di rumah. Bentuk komunikasi yang lebih rumit mendorong penyampaian pesan oleh komunikator kepada komunikan dilakukan melalui sejumlah strategi komunikasi yang canggih, setelah melewati proses perencanaan yang matang.

Komunikasi pemasaran dapat juga dinyatakan sebagai kegiatan komunikasi yang ditujukan untuk menyampaikan pesan kepada konsumen dan pelanggan dengan menggunakan sejumlah media dan berbagai saluran yang dapat dipergunakan dengan harapan terjadinya tiga tahapan perubahan, yaitu :

a. Tahap pertama Perubahan pengetahuan, dalam perubahan ini konsumen mengetahui adanya keberadaan sebuah produk, untuk apa produk itu diciptakan, dan ditujukan kepada siapa produk tersebut, dengan demikian pesan

14 Onong Uchjana Efendi, Ilmu Komunikasi Teori dan Praktek, (Bandung: Remaja Rosda Karya, 2009), 10. 
yang disampaikan tidak lebih menunjukkan informasi penting dari produk.

b. Tahap kedua adalah perubahan sikap yang ditentukan oleh tiga komponen yaitu pengetahuan, perasaan, perilaku.perubahan yang diharapkan adalah mengarah kepada keinginan untuk mencoba produk, yaitu pembelian atau setidaknya konsumen melakukan sebuah pengujian terhadap ketepatan produk.

c. Tahap ketiga yaitu perubahan perilaku, dengan tujuan agar konsumen tidak beralih kepada produk lain, dan terbiasa menggunakannya. Definisi lain yang dapat diberikan untuk komunikasi pemasaran adalah kegiatan pemasaran dengan menggunakan teknik-teknik komunikasi yang ditujukan untuk memberikan informasi kepada orang banyak dengan harapan agar tujuan perusahaan tercapai, yaitu terjadinya peningkatan pendapatan (laba) sebagai hasil penambahan penggunaan jasa atau pembelian produk yang ditawarkan.

Dengan demikian, komunikasi pemasaran merupakan bentuk komunikasi yang ditujukan untuk memperkuat strategi pemasaran, guna meraih segmentasi yang luas dan juga sebagai jumlah upaya untuk memperkuat loyalitas pelanggan terhadap produk yaitu barang dan jasa yang dimiliki perusahaan. Komunikasi pemasaran yang efektif sangat menentukan keberhasilan pemasaran. Konsumen akan memahami pesan yang disampaikan, dan tertarik untuk membeli produk atau jasa yang ditawarkan jika pemasar melakukan komunikasi pemasaran yang efektif.

\section{Strategi Komunikasi Pemasaran}

Dalam konteks komunikasi, strategi diperlukan untuk mendukung kekuatan pesan agar mampu mengungguli semua kekuatan yang ada untuk menciptakan efektivitas komunikasi. Komunikasi yang efektif adalah komunikasi yang hasilnya sesuai degan harapan para pesertanya (orang-orang yang terlibat dalam proses komunikasi).

Strategi komunikasi merupakan paduan dari perencanaan komunikasi (communication planning) dan manajemen komunikasi (communication management) untuk mencapai tujuan yang telah ditetapkan, yang menurut Effendy, terdiri dari tiga hal utama : untuk mengamankan pemahaman (to secure understanding), untuk menetapkan penerimaan (to establish acceptance), dan untuk melakukan motif (to motive actions). Pertama adalah memastikan bahwa komunikan mengerti pesan yang diterimanya (to secure understanding). Andaikan komunikan telah mengerti dan menerima, maka penerimaannya harus dibina (to establish acceptance), dan pada akhirya kegiatan dimotivasikan (to motive actions). Strategi komunikasi ini selanjutnya 
juga harus mampu menunjukkan bagaimana operasionalisasinya secara praktis yang harus dilakukan, dalam arti kata bahwa pendekatan bisa berbeda-beda tergantung situasi dan kondisi yang didapati di lapangan.

Dari pandangan tersebut, terlihat bahwa langkah awal dalam menerapkan sebuah strategi komunikasi adalah menyusun perencanaan komunikasi. Ada beberapa pinsip yang perlu diperhatikan dalam merencanakan komunikasi, yakni :

a. Rencana merupakan patokan bersama sehingga harus mencerminkan aspirasi bersama (bukan keputusan perorangan).

b. Implementasi rencana biasanya melibatkan masyarakat, oleh karena itu penting sekali untuk mendengarkan dan mempertimbangkan aspirasi masyarakat (bottom up) dan bersifat partisipatif.

c. Rencana yang disusun harus bersifat fleksibel, tidak kaku, sehingga memudahkan ketika terjadi perubahan dan penyesuaian.

d. Rencana komunikasi harus disusun secara jelas dan konkrit. Di dalamnya harus mengandung what to do dan how to do yang jelas dan pasti agar tidak menimbulkan penafsiran yang bermacammacam yang akan membingungkan pelaksanaannya.

15 Tine Silvana R., Jurnal Komunikasi pemasaran :Konsep dan penerapannya pada
Sedangkan untuk Strategi marketing terdiri atas lima elemen yang saling terkait. Kelima elemen tersebut adalah :

a. Pemilihan pasar; yaitu memilih pasar yang akan dilayani. Pemilihan pasar dimulai dengan melakukan segmentasi pasar dan kemudian memilih pasar sasaran yang paling memungkinkan untuk dilayani oleh Organisasi/Perusahaan.

b. Perencanaan produk, meliputi produk spesifik yang dijual, pembentukan lini produk, dan desain penawaran individual pada masing-masing lini.

c. Penetapan harga, yaitu menentukan harga yang dapat mencerminkan nilai kuantitatif dari produk kepada pelanggan / kustomer.

d. Sistem distribusi, yaitu saluran perdagangan grosir dan eceran yang dilalui produk hingga mencapai konsumen akhir yang membeli dan menggunakannya.

e. Komunikasi pemasaran (promosi), yang meliputi periklanan, personal selling, promosi penjualan, direct marketing, dan public relations

Kemampuan strategi marketing menanggapi setiap perubahan kondisi pasar dan faktor biaya tergantung pada analisis terhadap faktor-faktor lingkungan, pasar, persaingan, analisis kemampuan internal, perilaku konsumen, dan analisis ekonomi. ${ }^{15} \mathrm{Di}$ 
samping itu, dalam merumuskan strategi komunikasi ada lima faktor yang harus diperhatikan, yaitu: mengenal khalayak, penyusunan pesan, penetapan metode, pemilihan media, dan peranan komunikator. Sejalan dengan pendapat tersebut, maka langkah- langkah dalam perencanaan komunikasi meliputi: pengumpulan data base line dan need assesment, merumuskan tujuan komunikasi, analisis perencanaan dan pengembangan strategi, analisis dan segmentasi khalayak, pemilihan media, mendesain dan mengembangkan pesan, perencanaan pengelolaan pelaksanaan program dan melaksanakan pelatihan keterampilan pada komunikator.

Strategi pada hakikatnya adalah perencanaan dan manajemen untuk mencapai suatu tujuan.Tetapi untuk mencapai tujuan tersebut, strategi tidak berfungsi sebagai peta jalan yang hanya menunjukkan arah saja, melainkan harus menunjukan bagaimana taktik operasionalnya.

Demikianlah strategi komunikasi merupakan paduan dan perencanaan komunikasi (communication planning) dan manajemen komunikasi (communication management) untuk mencapai suatu tujuan. Untuk mencapai tujuan tersebut strategi komunikasi harus dapat menunjukan bagaimana operasionalnya secara taktis harus dilakukan dalam arti kata bahwa

${ }^{16}$ Denzin \& Lincoln, Handbook of Qualitative Research, (Yogyakarta: Pustka Belajar, 2009), 6-7. pendekatan (approach) bisa berbeda sewaktu-waktu bergantung dari situasi dan kondisi. Strategi komunikasi merupakan penentu berhasil tidaknya kegiatan komunikasi secara efektif.

\section{Metode Penelitian}

Jenis penelitian yang digunakan dalam penelitian kali ini adalah deskriptif kualitatif, Sebagaimana yang dikatakan Denzin dan Lincon, bahwa penelitian kualitatif adalah penelitian yang menggunakan latar ilmiah, dengan maksud menafsirkan fenomena yang terjadi dan dilakukan dengan jalan melibatkan metode yang ada. Sudut pandang peneliti dalam penelitian kali ini adalah sebagai seorang pengamat yang berusaha memahami permasalahan yang terjadi. Penelitian kualitatif lebih menekankan pada persoalan kedalaman (kualitas) data bukan banyaknya (kuantitas) data. ${ }^{16}$

Pendekatan yang digunakan adalah pendekatan pendekatan manajemen. objektivitasnya dibangun diatas rumusan pendekatan yang berpusat pada prinsipprinsip yang dapat digunakan oleh manajer untuk koordinasi kegiatan dlm organisasi. Pendekatan ini menitik beratkan pada para manajer. ${ }^{17}$

\section{Hasil dan Pembahasan}

Gambaran Umum Wisata Bukit Kapur SETIGI Wisata alam Bukit Kapur (SETIGI) berlokasi di perbatasan antara Desa Sekapuk dengan Desa Gosari. Dengan letak lokasi yang sangat strategis

${ }^{17}$ Sugeng Pujileksono, Metode Penelitian Komunikasi Kualitatif. (Malang: Intrans Publishing, 2015), 64-65. 
dekat dengan jalan raya antar desa menjadikan wisata ini mudah dalam akses jalannya. Dengan luas lahan luas tanah 4,6 hektar. Wisata Bukit Kapur (SETIGI terletak di Desa Sekapuk, Kecamatan Ujungpangkah, Kabupaten Gresik, Provinsi Jawa Timur, Indonesia. Untuk menuju lokasi wisata bukit kapur SETIGI bisa melalui beberapa jalan besar penghubung antar Desa. Dari arah Timur bisa melewati Desa Wadeng, Sidayu. Dari arah Barat bisa melewati Desa Panceng, dan dari arah Selatan bisa melewati Desa Gosari. Semua jalan bisa diakses oleh kendaraan pribadi maupun Bus Pariwisata.

Wisata Wisata bukit kapur (SETIGI) dibangun dengan tujuan untuk melestarikan keberadaan perbukitan kapur yang sudah semakin habis kondisi fisiknya oleh aktifitas pertambangan yang dilakukan sejak 1962 sampai sekarang. Dengan faktor tersebut pemerintah Desa Sekapuk memutuskan untuk mengambil alih sebagian lahan yang dulunya dikelolah oleh PT.POLOWIJO GOSARI untuk dikelolah oleh pemerintah daerah Sekapuk untuk dijadikan sebagai obyek wisata alam penghijauan yang bertema keluarga. Dengan dibangunnya wisata Bukit Kapur (SETIGI) ini Pemerintah Desa berharap dapat melestarikan warisan alam tersebut. Kemudian dilakukan grand opening untuk peresmian obyek wisata tersebut pada tanggal pada tanggal 11 Mei 2018 oleh Kepala Desa Sekapuk Bapak Abdul Halim dan selaku pimpinan pengelolah wisata tersebut.

Yang dimaksud dalam galihan pertambangan ini adalah dan karena aktifitas warga dulu sampai sekarang warga Desa Sekapuk dan sekitarnya mayoritas bekerja sebagai buruh tambang batu kapur di bukit kapur sekapuk. Karena di terus digali dan diambil hasil buminya akhirnya saat ini meninggalkan bekasbekas galian yang membentuk seperti goa, tebing-tebing yang menjulang dan sangat indah seperti bangunan di peradaban kuno. Yang paling disukai wisatawan disini adalah tebing-tebing bekas galian tersebut banyak membentuk lorong, goa dan menyisakan tiang-tiang kokoh dari batu kapur yang menjadi simbol SETIGI dan menjadi tempat favorit bagi wisatawan untuk dijadikan spot-spot foto selfi. wisatawan sekitar SETIGI akan berkunjung di sore hari untuk melihat sunset di SETIGI.

Wisata Bukit Kapur SETIGI terkenal sebagai tempat untuk berfoto karena background yang sangat unik dan indah. Strategi atau upaya yang digunakan oleh pihak SETIGI guna menarik pengunjung, yang pertama adalah dengan cara mempromosikan melalui media cetak maupun elektronik, namun tanpa adanya promosi pun wisatawan tertarik dengan sendirinya untuk mengunjungi SETIGI,

Penelitian adalah kegiatan pengumpulan data, dengan tujuan untuk menjelaskan dan menjabarkan informasi, fakta, dan data-data yang telah diperoleh peneliti dari lapangan baik data primer maupun sekunder. Setelah dikumpulkan, data disusun dan diolah kemudian di tarik kesimpulan yang bersifat umum. Peneliti harus benar-benar memahami berbagai hal yang berkaitan dengan pengumpulan data. Peneliti memproses data-data tentang Strategi Bauran Komunikasi Pemasaran 
wisata Bukit Kapur (SETIGI) khususnya langkah-langkah dan strategi yang dilakukan oleh pihak pengelolah dalam menarik pengunjung.

\section{Model Proses Strategi Bauran Komunikasi Pemasarana di Wisata Bukit Kapur (SETIGI)}

Wisata Bukit Kapur memiliki Visi dan Misi sebagai Wisata alam yang memiliki fungsi sebagai pelestarian dan penghijauan baik dari kalangan anak-anak sampai orang dewasa yang datang dan menjadi tujuan berlibur baik masyarakat lokal maupun mancanegara. Dan Wisata Bukit Kapur (SETIGI) ingin membuat image wisata alam yang identik dengan bebatuan alami dengan suana yang hijau dan rindang sehingga menjadi wisata alam yang nyaman dan enak untuk di kunjungi.

Namun hambatan utama wisata alam ini adalah dari faktor dana dikarenakan sumber dana hanya melalui BUMDES saja jadi butuh proses lama dalam pembangunan. Sumber dana yang kurangRespon persepsi dan inteprestasi yang diterima pihak pengelolah Wisata Bukit Kapur (SETIGI) dari kalangan masyarakat sangat positif sekali. Dimana memang kota industri dengan segudang aktifitas perekonomian Gresik membutuhkan Wisata Bukit Kapur untuk melestarikan kekayaan alam Kota Gresik agar bias dinikmati oleh masyarakat luas.

\section{Proses membuat Perencanaan IMC di Wisata Bukit Kapur (SETIGI)}

Pada tahap ini kegiatan yang paling penting dilakukan terlebih dahulu adalah membuat Segmentasi pasar. Dalam perumusan atau perencanaan strategi, Wisata Bukit Kapur (SETIGI) menganggap bahwa hal yang terlebih dahulu menjadi fokus ada tiga yang digagas bapak Abdul Halim selaku penanggung jawab Wisata Bukit Kapur (SETIGI) yaitu Sounding kepada masyarakat dengan mengkomunikasikan tentang eksistensi SETIGI itu sendiri.

Kedua mengadakan program-program kegiatan baik kegiatan-kegiatan yang reguler maupun yang isidentil, dimana program-program itu bisa menjadi daya tarik kepada publik dan menunjang Wisata Bukit Kapur (SETIGI) yang juga merupakan bagian dari pelayanan kepada Publik. Dan yang ketiga adalah Mempromosikan baik bersinergi dengan Dinas Pariwisata, Pihak swasta seperti Hotel, Tour Agen dan travel juga lewat media sosial. Karena target audience atau target pengunjung Wisata Bukit Kapur (SETIGI) adalah segmentatif seperti keluarga dan kalangananak muda, ada Turis Lokal dan Mancanegara. Sehingga Wisata Bukit Kapur (SETIGI) mengkemas sedemikian rupa agar sounding itu benarbenar efektif masuk di berbagai kalangan.

Sounding pertama ditujukan kepada segmentasi orang dewasa, anak muda (pelajar) baik dari tingkat Taman kanakkanak sampai tingkat Mahasiswa. Untuk segmentasi pelajar pihak Wisata Bukit Kapur (SETIGI) melakukan promosi melalui media sosial dimana dalam program/kegiatan tersebut untuk strategi tersebut sudah berjalan selama satu setengah tahun terakhir ini. Sebagai wisata alam keluarga, Wisata Bukit Kapur (SETIGI) bahkan memberikan pelayanan 
khusus dimana setiap masyarakat Desa Sekapuk yang ingin masuk di Wisata Bukit Kapur (SETIGI) gratis biaya masuk dengan membawa KTP saja.

Berkerjasama dengan UPTD maupun Dinas pariwisata sebagai pihak dari pemerintah dan bekerjasama dengan stakeholder seperti Agen tour \& Travel, Hotel serta pihak swasta lain seperti Event Majapahit Travel Fair (MTF) yang diwaliklakn oleh Cak Yuk Kota Gresik dalam event tersebut Cak Yuk memperkenalkan wisata, budaya, kuliner apa aja yang dimiliki Kota Gresik salah satunya wisata bukit kapur setigi. Sedangkan untuk wisatawan umum baik dari dalam negeri maupun wisatawan mancanegara dikenai biaya masuk wisata sebesar Rp. 5000,- dimana harga tersebut mengacu pada PERDA yang menetapkannya. Dan ada harga khusus buat pengunjung yang datang secara rombongan.

Selain berkerjasama dengan Pemerintah, dinas terkait dan para stakeholder swasta seperti agent \& Travel, Hotel dan Perusahaan swasta lain. Pihak Pengelolah Wisata Bukit Kapur (SETIGI) juga bekerjasama dengan komunitas komunitas anak muda seperti Komunitas Matic se Indonesia, Komunitas RX King, Komunitas Pick Up. Komunitas Matic se Indonesia yaitu komunitas yang para anggotanya menggunakan sepeda Matic dan anggotanya menyebar seluruh Indonesia mulai dari Kota Gresik, Surabaya, Sragen, Timika, Mojoagung, Babat, Tuban, Mojokerto, Mojosari, Jombang, Solotigo, Boyolali, Lamongan, Krian, Surakarta, Bondowoso, Pandaan,
Kediri, Ploso, Sidoarjo, Madiun, Klaten.ikut hadir di acar bulanan tersebut dan berkunjung ke SETIGI mereka juga sering melakukan aksi mereka selama perjalanan touring. Dimana pihak Wisata Bukit Kapur (SETIGI) ini juga menjalin kerjasama dengan komunitas ini.

Sehingga komunitas sepedamotor ini melakuan pertunjukan di setiap bulannya di depan Wisata BukitKapur (SETIGI). Dimana kegiatan tersebut bisa menjadi hubungan sesame komunita yang ingin berkunjung ke Wisata Bukit Kapur (SETIGI) Dimana publik masyarakat atau wisatawan bisa melihat aksi komunitas ini secara gratis. Sehingga ini cocok untuk mengisi liburan keluarga.Dan para wisatawan pun supaya bisa tertarik untuk mengunjungi Wisata Bukit Kapur (SETIGI). b. Menyusun Strategi dan Taktik Strategi adalah cara untuk mencapai tujuan. Sedangkan taktik adalah tindakan yang bersifat taktis sesuai dengan kondisi lapangan dalam menunjang strategi yang sudah ditetapkan. Strategi Bauran Komunikasi Pemasaran Wisata Bukit Kapur (SETIGI) selain menggunakan pendekatan jaringan seperti melalui media sosial, pengelolah masih mempertahankan Komunikasi Pemasaran secara konvensional yaitu melalui pemasangan pamflet yang dipasang sepanjang jalan besar dan pintu masuk Desa Sekapuk dan Trik-trik strategi komunikasi SETIGI juga melalui sosialisasi ke komunitaskomunitas pemuda.

Dari taktik tersebut maka Wisata Bukit Kapur (SETIGI) dapat dengan mudah mendapatkan sponsor tatkala akan mengadakan event bulanan. Dan tak jarang 
mereka seperti Media akan menawarkan diri terlebih dahulu agar bisa membantu terselenggaranya sebuah event bulanan bahkan tahunan tersebut tanpa di minta oleh Wisata Bukit Kapur (SETIGI). Biasanya mereka akan dengan sukarela membantu dengan latar belakang mereka masing masing. Jika latar belakangnya adalah sebuah perusahaan di bidang media, maka mereka akan menginformasikan kepada khalayak mengenai kegiatan yang akan dilaksanakan oleh Wisata Bukit Kapur (SETIGI), baik itu media cetak maupun elektronik. Dan bila perusahaan itu bergerak di bidang jasa seperti Hotel, Tour \& Travel dan perusahaan swasta lain, maka mereka akan dengan senang hati membantu untuk membawa wisatawan domestik maupun mancanegara agar bersedia mengunjungi Wisata Bukit Kapur (SETIGI) saat kegiatan sedang berlangsung. Dan Pihak pengelolah Wisata Bukit Kapur (SETIGI) juga mengikuti perkembangan Media Sosial Internet dengan membuat akun.

\section{Kesimpulan}

Peneliti dapat menarik kesimpulan bahwa, dalam Strategi Bauran Komunikasi Pemasaran BUMDES dan Pokdarwis Pelangi dalam menarik pengunjung ke Wisata Bukit Kapur (SETIGI) Di Desa Sekapuk Kecamatan Ujungpangkah Kabupaten Gresik adalah 1) Dengan menerapkan Harga yang murah untuk tiket masuk ke Wisata Bukit Kapur (SETIGI). 2) Promosi melalui Media Cetak, Media Social, maupun Media Elektronik. 3) Mengundang komunitas-komunitas anak muda setiap bulannaya (komunitas matic
se-Indonesia, komunitas R-King) untuk melakukan Show di Lokasi Wisata Bukit Kapur (SETIGI). 4) Bekerjasama dengan macam-macam Media, para Stakeholder, Pemerintah, Tour\&Travel, Hotel dan perusahan swasta untuk bersinergi dan bekerjasama dalam strategi bauran komunikasi pemasaran yang dilakukan oleh pengelolah Wisata Bukit Kapur (SETIGI) di Desa Sekapuk Kecamaan Ujungpangkah Kabupaten Gresik.

\section{Daftar Pustaka}

Abdullah, Thamrin dkk. Manaajemen Pemasaran. Jakarta: PT. Raja Grafindo Persada, 2013.

Anam, Samsul dkk. Manajemen pemasaran. Surabaya: IAIN Sunan Ampel Pers, 2013.

Arifin, Anwar. Strategi Komunikasi. Bandung: Armico, 1984.

Badan Pusat Statistik. "Laporan Bulanan Data Sosial Ekonomi Juli 2018 (Publikasi BPS)". diakses 28 Juli 2018. www.bps.go.id

Budi, Rio Prasadja Tan. Kunci Sukses Memasarkan Jasa Pariwisata. Jakarta: Penerbit Erlangga, 2010.

Hafied, Cangara. Perencanaan dan Strategi Komunikasi. Jakarta: Raja Grafindo Persada, 2013.

Kolter, Philip dan Kevin Lane Keller. Marketing Management millenium Edition. New Jersey: Pearson Education, 2009. 
Lincoln \& Denzin. Handbook of Qualitative Research. Yogyakarta: Pustaka Belajar, 2009.

Manullang, M. Esterlina Hutabarat. Manajemen Pemasaran Jasa. Yogyakarta: Indomedia Pustaka, 2016.

Mattew B, Milles \& A. Michael Huberman. Analisis Data Kualitatif. Jakarta: Universitas Indonesia, 2007.

Morrison, Alastar M. Hospitallity \& Travel Marketing 4th Edition. New York: Delmar Cengage Learning, 2010.

Mudjiono, Yoyon. Ilmu Komunikasi. Surabaya: Jaudar Press, 2012.

Prasadja, Budi Tan Rio. Kunci Sukses Memasarkan Jasa Pariwisata. Jakarta: Penerbit Erlangga, 2010.

Pujileksono, Sugeng. Metode Penelitian Komunikasi Kualitatif. Malang: Intrans Publishing, 2015.

Rahmat, Jalaluddin. Metode Penelitian Komunikasi. Bandung: Remaja Rosdakarya, 1999.

Rangkuti, Freddy. Strategi Promosi Yang Kreatif dan analisis kasus Integrated Marketing Communication. Jakarta: Gramedia Pustaka Utama, 2009.

Rohim, Syaiful. Teori Komunikasi perspektif, Ragam dan Aplikasi. (Jakarta: Rineka Cipta, 2009.

TipsSerbaSerbi. "Pengertian Marketing Mix”. Diakses, 22 Oktober 2018.

http://tipsserbaserbi.blogspot.co.id/2016/0 2/pengertian-marketting-mix-4p-dan7p.html?m=1
Uchjana Efendi, Onong. Ilmu Komunikasi Teori dan Praktek. Bandung: Remaja Rosda Karya, 2009.

Uchjana, Onong Effendy. Ilmu Komunikasi (Teori dan Praktek). Bandung: PT Remaja Rosdakarya, 2007.

Wijaya, David "Pemasaran Jasa Pendidikan”. Jakarta: Bumi Aksara, 2016. 